\title{
Filtered mud improves sugarcane growth and modifies the functional abundance and structure of soil microbial populations
}

\author{
Ahmad Yusuf Abubakar 1,2,3 , Muhammed Mustapha Ibrahim ${ }^{4,5}$, Caifang Zhang ${ }^{1,2}$, Muhammad Tayyab ${ }^{1,2}$, Nyumah \\ Fallah $^{1,2}$, Ziqi Yang ${ }^{1,2}$, Ziqin Pang ${ }^{1,2}$, Hua Zhang ${ }^{\text {Corresp. } 1,2}$

Background. Exploring high-quality organic amendments has been a focus of sustainable agriculture. Filtered mud (FM), a sugar factory waste derived from sugarcane stems, could be an alternative organic amendment for sugarcane production. However, the effects of its application proportions on soil fertility, nutrient cycling, structure of soil bacterial and fungal communities, and the growth of sugarcane in clayloam soils remain unexplored.

Methods. Three application proportions of FM: (FM1-(FM: Soil at 1:4), FM2-(FM: Soil at 2:3), and FM3-(FM: Soil at 3:2)) were evaluated on sugarcane growth and soil nutrient cycling. High throughput sequencing was also employed to explore soil microbial dynamics.

Results. We observed that FM generally increased the soil's nutritional properties while improving $\mathrm{NO}_{3}{ }^{-}$ retention compared to the control, resulting in increased growth parameters of sugarcane. Specifically, FM1 increased the concentration of $\mathrm{NH}_{4}{ }^{+}-\mathrm{N}$, the $\mathrm{N}$ fraction preferably taken up by sugarcane, which was associated with an increase in the plant height, and more improved growth properties, among other treatments. An increase in the proportion of FM also increased the activity of soil nutrient cycling enzymes; urease, phosphatase, and $\beta$-glucosidase. High throughput sequencing revealed that FM reduced the diversity of soil bacteria while having insignificant effects on fungal diversity. Although increasing FM rates reduced the relative abundance of the phyla Proteobacteria, its class members, the Gammaproteobacteria and Betaproteobacteria containing some N-cycling related genera, were stimulated. Also, FM stimulated the abundance of beneficial and lignocellulose degrading organisms. These included the bacterial phyla Actinobacteria, Bacteriodates, Acidobacteria, Chloroflexi, and the fungal phylum Ascomycota. The distribution of the soil microbial community under FM rates was regulated by the changes in soil pH and the availability of soil nutrients. Since FM1 showed more promise in improving the growth properties of sugarcane, it could be more economical and sustainable for sugarcane production in clay-loam soils. 
1 Filtered mud improves sugarcane growth and modifies the functional abundance and structure of soil microbial populations

$4 \quad$ Ahmad Yusuf Abubakar ${ }^{1,2,3}$, Muhammed Mustapha Ibrahim ${ }^{4,5}$, Caifang Zhang ${ }^{1,2}$, Muhammad

$7{ }^{1}$ Key Laboratory of Sugarcane Biology and Genetic Breeding, Ministry of Agriculture, Fujian

8 Agriculture and Forestry University, Fuzhou, China

$9{ }^{2}$ College of Agriculture, Fujian Agriculture and Forestry University, Fuzhou, China

103 Bioresources Development Centre, Kano; National Biotechnology Development Agency 11 (NABDA) Abuja, Nigeria

$12{ }^{4}$ Department of Soil Science, University of Agriculture, Makurdi, Nigeria

135 Key Research Laboratory of Soil Ecosystem Health and Regulation in Fujian Provincial 14 University, College of Resources and Environment, Fujian Agriculture and Forestry University, 15 Fuzhou, Fujian Province, China.

$16 *$ Corresponding author

17 Email: zhanghua4553@sina.com (H.Zhang) 


\begin{abstract}
Exploring high-quality organic amendments has been a focus of sustainable agriculture.
\end{abstract} Filtered mud (FM), a sugar factory waste derived from sugarcane stems, could be an alternative organic amendment for sugarcane production. However, the effects of its application proportions on soil fertility, nutrient cycling, structure of soil bacterial and fungal communities, and the growth of sugarcane in clay-loam soils remain unexplored. Three application proportions of FM: (FM1(FM: Soil at 1:4), FM2-(FM: Soil at 2:3), and FM3-(FM: Soil at 3:2)) were evaluated on sugarcane growth and soil nutrient cycling. High throughput sequencing was also employed to explore soil microbial dynamics. We observed that FM generally increased the soil's nutritional properties while improving $\mathrm{NO}_{3}{ }^{-}$retention compared to the control, resulting in increased growth parameters of sugarcane. Specifically, FM1 increased the concentration of $\mathrm{NH}_{4}{ }^{+}-\mathrm{N}$, the $\mathrm{N}$ fraction preferably taken up by sugarcane, which was associated with an increase in the plant height, and more improved growth properties, among other treatments. An increase in the proportion of FM also increased the activity of soil nutrient cycling enzymes; urease, phosphatase, and $\beta$-glucosidase. High throughput sequencing revealed that FM reduced the diversity of soil bacteria while having insignificant effects on fungal diversity. Although increasing FM rates reduced the relative abundance of the phyla Proteobacteria, its class members, the Gammaproteobacteria and Betaproteobacteria containing some N-cycling related genera, were stimulated. Also, FM stimulated the abundance of beneficial and lignocellulose degrading organisms. These included the bacterial phyla Actinobacteria, Bacteriodates, Acidobacteria, Chloroflexi, and the fungal phylum Ascomycota. The distribution of the soil microbial community under FM rates was 
44 regulated by the changes in soil $\mathrm{pH}$ and the availability of soil nutrients. Since FM1 showed more

45 promise in improving the growth properties of sugarcane, it could be more economical and

46 sustainable for sugarcane production in clay-loam soils.

47 Keywords: soil enzymes; filtered mud; soil fertility; bacteria; fungi; high-throughput sequencing

48

\section{Introduction}

Sugarcane (Saccharum officinarum L.) is a globally important crop that contributes significantly to the raw materials needed in sugar and biofuel-producing industries (Khalil et al., 2018). It is cultivated in the tropical and subtropical regions of the world and has an annual output of approximately 16 million tons (Fallah et al., 2021). Over the years, there has been extensive use of inorganic fertilizers, especially nitrogen $(\mathrm{N})$, in sugarcane production to meet its increasing industrial demands (Azeem et al., 2014; Thorburn et al., 2017). However, the excessive application of these chemical fertilizers does not always show a continuous positive effect on crop production (Vitousek et al., 2009; Bei et al., 2018). Instead, it can result in low nutrient use efficiency and soil acidification (Bei et al., 2018), eutrophication and leaching (Ibrahim et al., 2020a), N deposition, as well as greenhouse gas emissions (Liu et al., 2013). Besides, the prolonged application of inorganic fertilizers could result in changes in the physical, chemical, and biological properties of the Soil (Rivera-Becerril et al., 2017). Alternatively, the use of organic fertilization to mitigate soil acidification and improve soil nutrient status, thus ensuring sugarcane productivity, is a promising approach. Organic amendments such as farmyard manure and crop residues have been shown to improve soil physicochemical properties, productivity, microbial community diversity, and 
64

65

66

67

68

69

70

71

72

73

74

75

76

77

78

79

80

81

82

83

composition compared to chemical fertilizers (Cesarano et al., 2017; Das et al., 2017). Therefore, the continuous exploration of several high-quality organic materials would also be beneficial in improving the soil's physical, chemical, and biological properties for crop production.

Filtered mud (FM) is a solid waste by-product produced from sugar mills during sugar production. It comprises about 3\% of the crushed sugarcane after sulphonation (Kumar et al., 2011) and 7\% after carbonation (Saleh-e-In et al., 2012). This results in a dark brown amorphous and soft solid comprising sugar, fiber, coagulated colloids, soil particles, inorganic salts, and several mineral elements in variable proportions (Joshi et al., 2010). Studies have shown that FM could effectively increase soil $\mathrm{pH}$, prevent soil erosion, crusting, cracking, improving drainage, and stimulate soil microbial abundance (Tandon, 1995). Its sole or combined application with chemical fertilizer has been shown to increase the organic carbon $(\mathrm{C})$, total nitrogen $(\mathrm{N})$, phosphorus $(\mathrm{P})$, and potassium (K) status of the Soil (Kaur et al., 2005). However, management systems utilizing organic amendments could have varying effects in stimulating the activity and diversity of soil microbial community and the nutrient content of the soil depending on their source and composition (Zhang et al., 2015). Unfortunately, there is limited information on the effects of FM on the changes in soil nutritional composition through its alteration of the diversity and composition of soil bacterial and fungal communities. Therefore, understanding the impact of different organic materials used in soil management on the shifts in soil microbial diversity and community abundance could help us understand soil nutrient cycling processes (Dai et al., 2017).

While several organic amendments have been evaluated for their potential in restoring soil 
84 fertility and productivity, the evaluation of FM in clay-loam soils under sugarcane cultivation has

85

86

87

88

89

90

91

92

93

94

95

96

97

98

99

100

101

102

103

104

not been documented. Adequate information on the effect of FM on soil quality, plant growth, and

soil bacterial and fungal diversity remains relatively scarce in soils having high water retention

capacity. Moreover, how different FM amendment proportions could alter the diversity and structure of soil microbial populations in the rhizosphere of sugarcane crops in such soils has not been previously reported. Also, the shift in fungal community composition may be influenced by the use of FM, as there has been evidence of fungal composition in FM (Tayyab et al., 2019). This could alter the general soil microbial diversity and balance when incorporated into the soil. Similarly, the relationship between soil bacterial and fungal diversity and structure with soil properties due to different FM rates requires adequate understanding. These, therefore, indicate significant knowledge gaps in understanding the effects of FM and its application rates on soil microbial diversity and functional abundance. Therefore, evaluating soil microbial dynamics using high-throughput sequencing will be helpful to reveal the complexity and diversity of microbial communities (Shendure \& Ji, 2008; Dai et al., 2017).

We hypothesize that different FM:soil ratios would have varying effects on the availability of soil nutrients, sugarcane growth, nutrient cycling enzyme activity, microbial diversity, and community structure in clay-loam soil. Therefore, the objectives of this study were; (a) to evaluate the effect of FM rates on soil nutrient supply potential and agronomic characteristics of sugarcane plants in clay-loam soil, (b) to investigate the diversity and relative abundance of soil bacterial and fungal communities after FM amendment, (c) to investigate the roles of soil properties in the dynamics of the bacterial and fungal community composition of the rhizosphere of sugarcane in a 
105

106

107

108

109

110

111

112

113

114

115

116

117

118

119

120

121

122

123

124

125

clay-loam soil amended with different FM proportions.

\section{Materials and Methods}

\section{Soil substrate preparation and experimental design}

The soil used for the experiment was collected from the Fujian Agriculture and Forestry University sugarcane cultivation field (latitude: $26^{\circ} 05$ 9.60" N; longitude: $119^{\circ} 143.60^{\prime \prime} \mathrm{E}$ ). The physicochemical properties of soil were; total carbon (TC): $0.97 \%$, total phosphorus (TP): $0.7 \mathrm{~g} / \mathrm{kg}$, and total nitrogen (TN): $0.10 \%$. The soil particle size distribution was clay $20.3 \%$ silt $43.1 \%$ sand $36.6 \%$, which was classified as clay-loam. The sugar mill filtered mud (FM) used in this experiment was obtained from Nanjing Qinfeng Crop Straw Technology Company, China. Before mixing with the soil, the FM was oven-dried at $50{ }^{\circ} \mathrm{C}$ until a constant weight was achieved. The chemical properties of the FM are as follows; $\mathrm{pH}: 7.28$, EC: $3.45 \mathrm{dS} / \mathrm{m}, \mathrm{O} . \mathrm{C}: 23.31 \%$, O.M: 40.1\%, $\mathrm{N}: 1.64 \%, \mathrm{P}: 14.4 \mathrm{~g} / \mathrm{kg}, \mathrm{K}: 14.1 \mathrm{~g} / \mathrm{kg}, \mathrm{Ca}: 1.33 \mathrm{cmol} / \mathrm{kg}, \mathrm{Mg}: 1.37 \mathrm{cmol} / \mathrm{kg}, \mathrm{S}: 1.52 \%$, and Na: 1.44 $\mathrm{cmol} / \mathrm{kg}$.

The experiment was carried out in a greenhouse at the Fujian Agriculture and Forestry University Fuzhou, Fujian Province, P.R China, from March to December 2019 using red PVC pots. Each pot had a height of $180 \mathrm{~mm}$ and a diameter of $120 \mathrm{~mm}$. The experimental soil was properly air-dried and sieved into a $2 \mathrm{~mm}$ size fraction and mixed according to the respective ratios with FM to give a total weight of $10 \mathrm{~kg}$ per pot. The treatments evaluated comprised of a control (CK) without any amendment and three different FM:soil ratios. These FM ratios were hypothetically selected to accommodate its possible proportions that can be used under various conditions, from fields requiring more soil to greenhouse cultivation requiring less soil. These 
126

127

128

129

130

131

132

133

134

135

136

137

138

139

140

141

142

143

144

145

treatments were: CK, FM1 (FM:soil at 1:4), FM2 (FM:soil at 2:3), and FM3 (FM:soil at 3:2). The

treatments were replicated three times and arranged in a randomized complete block design.

After mixing the soil and FM according to the respective proportions, the pots were watered

to field capacity and left for 24 hours to equilibrate. Sugarcane stems were planted vertically in

each pot and periodically irrigated to field capacity using tap water. Each pot was also kept weed-

free by hand weeding throughout the experimental period. During the experiment, the air

temperature recorded was $25-27^{\circ} \mathrm{C}$, and relative humidity of $75-80 \%$ was maintained throughout

the experiment. The agronomic characteristics (as listed in the plant data collection section) of the

sugarcane plants were recorded at the tillering stage, which signified the period of rapid nutrient

uptake for reproductive growth.

At the plant's tillering stage (90 days after planting), about $40 \mathrm{~g}$ of soil sample was collected from each pot's root zone using a portable soil auger of $1 \mathrm{~cm}$ diameter. Six subsamples were taken around and within the root zone of the crop per pot up to a depth of $18 \mathrm{~cm}$ to represent the rhizosphere soil and bulked to form a composite. A subsample of fresh soil was taken and put in well-labeled bags and stored in a refrigerator at $4{ }^{\circ} \mathrm{C}$ for the evaluation of the soil enzyme activity.

Part of the subsampled soil was air-dried, ground, and sieved using a 2-mm sieve to analyze the soil's physicochemical properties. About $10 \mathrm{~g}$ of the fresh soil subsamples were collected and stored at $-20{ }^{\circ} \mathrm{C}$ for DNA extraction.

\section{Chemical properties of the soil}

The $\mathrm{pH}$ of the soil samples was measured with a glass electrode $\mathrm{pH}$ meter using 1:2.5

Peer) reviewing PDF | (2021:08:64627:2:1:NEW 23 Nov 2021) 
146 (weight/volume) soil:water ratio (Ibrahim et al., 2020b). Electrical conductivity (EC) was

147 measured with a conductivity meter, while the soil total $\mathrm{C}$ and $\mathrm{N}$ were measured using the Flash

148 Smart elemental analyzer (Thermo Scientific ${ }^{\mathrm{TM}}$, Waltham, MA, USA). The soil available K was

149 determined by extraction using the ammonium acetate method and measured using flame

150 photometry (Pansu \& Gautheyrou, 2007). The molybdenum blue method was used to measure the

151 available phosphorus (AP). Soil ammonium $\left(\mathrm{NH}_{4}^{+}\right)$and nitrate $\left(\mathrm{NO}_{3}^{-}\right)$were extracted using $2 \mathrm{M}$

$152 \mathrm{KCl}$, and measured by a Bran+Luebbe GmbH-AutoAnalyzer 3 (Bran+Luebbe, Norderstedt,

153 Germany). The activities of the soil urease, phosphatase, $\beta$-Glucosidase, and cellulase were

154 measured as described by Sun et al. (2014). Soil urease activity assay was based on the $\mathrm{NH}_{4}{ }^{+}-\mathrm{N}$

155 released when the samples were incubated with $10 \mathrm{ml}$ of $10 \%$ urea solution and $20 \mathrm{~mL}$ of citric

156 acid buffer ( $\mathrm{pH}$ 6.7) at $37{ }^{\circ} \mathrm{C}$ for $24 \mathrm{~h}$. Cellulase activity assay involved the determination of

157 reducing sugars produced when the soil sample was incubated with acetate buffer $(50 \mathrm{mM}, \mathrm{pH}$

158 5.5), carboxymethyl cellulose, and toluene at $37^{\circ} \mathrm{C}$ for $24 \mathrm{~h}$ (Deng and Tabatabai, 1994). Soil

159 phosphatase activity was determined after incubating the samples with $0.25 \mathrm{~mL}$ of toluene and 1

$160 \mathrm{~mL}$ of disodium p-nitrophenyl phosphate tetrahydrate and placed in a water bath for $1 \mathrm{~h}$ at $37^{\circ} \mathrm{C}$

161 (Tabatabai and Bremner, 1969). The assay for the determination of the $\beta$-glucosidase enzyme

162 activity was carried out after incubating the samples with $50 \mathrm{mM}$ cellobiose substrate solution in

163 citrate-phosphate buffer ( $\mathrm{pH}$ 6.30) in a shaker at $37^{\circ} \mathrm{C}$ for $1 \mathrm{~h}$ (Stege et al., 2010).

164 Plant data collection

165 The plants' height (PLH) and diameter (PLD) were measured with the aid of a meter rule and 
166 Vernier caliper, respectively. The PLH in each pot was measured from the base of the plant to the

167 top visible dewlap (TVD) leaf. The Vanier caliper was used to measure the stalk diameter around

168 the middle of the stalk. The number of leaves (NL) and the number of tillers (NT) on each plant

169 were counted and averaged at the tillering stage. In addition, the leaves' chlorophyll content (Chol)

170 was measured using a chlorophyll meter (SPAD-502, Minolta, Japan).

171 Soil genomic DNA extraction and amplicon sequencing

172 The total genomic DNA of the soil was extracted from $0.5 \mathrm{~g}$ of each soil sample using the Fast

173 DNA ${ }^{\mathrm{TM}}$ Spin kit for soil following the manufacturer's instructions (MP Biomedical, Solon, OH,

174 USA). The extracted soil DNA's quality was visualized on 1\% gel electrophoresis and assessed

175 using a NanoDrop ND-2000 spectrophotometer (NanoDrop Technologies, Thermo Scientific,

176 USA). The DNA concentration was thereafter quantified using the Qubit assay (Invitrogen, CA).

177 The amplification of the v3-v4 region of the 16S rRNA genes in the extracted DNA as well as the

178 v4 region of $18 \mathrm{~S}$ rRNA were carried out using the polymerase chain reaction (PCR). The

$179341 \mathrm{~F} / 797 \mathrm{R}$ forward and reverse primers with barcodes were used for the PCR amplification of the

180 16S rRNA genes (Caporaso et al., 2010), while the 1176F/1536R were used for that of the 18S

181 rRNA genes (Smit et al., 1999). The PCR amplification was carried out on each samples using

182 three replicates, with a mixture containing $4 \mu \mathrm{L}$ of $5 \times$ Reaction Buffer, $2 \mu \mathrm{L}$ of dNTPs $(2.5 \mathrm{mM})$,

$1830.25 \mu \mathrm{L}$ of TransStart Fastpfu DNA Polymerase, $1 \mu \mathrm{L}$ of each primer $(5 \mu \mathrm{M})$ (reverse and forward),

184 and 10 ng template DNA (Michelsen et al., 2014). The PCR conditions involved an initial 
185

186

187

188

189

190

191

192

193

194

195

196

197

198

199

200

201

202

203

denaturation of $98^{\circ} \mathrm{C}$ for $1 \mathrm{~min}$, followed by 30 cycles of denaturation at $98^{\circ} \mathrm{C}$ for $10 \mathrm{~s}$, annealing at $50{ }^{\circ} \mathrm{C}$ for $30 \mathrm{~s}$, extension at $72{ }^{\circ} \mathrm{C}$ for $60 \mathrm{~s}$, and a final extension at $72{ }^{\circ} \mathrm{C}$ for $5 \mathrm{~min}$. A $2 \%$ agarose gel electrophoresis was carried out to visualize the amplified DNA. The amplified PCR products were thereafter recovered by cutting the gel using the AxyPrep DNA Gel Recovery Kit (Axygen Biosciences, CA, US). Samples that are characterized by one bright main strip between $400 \mathrm{bp}$ and $450 \mathrm{bp}$ were selected for further sequencing. The purification of the obtained PCR product was subsequently done using a Gel Extraction kit (TIANGEN, Beijing, China). An equal concentration of the purified amplicons was mixed into a single tube for sequencing. The initiation of the sequencing libraries was carried out in Illumina with the aid of a specific NEB Next ${ }^{\circledR}$ Ultra $^{\mathrm{TM}}$ DNA Library Prep Kit. The library sequencing quality having an average insert size of 400 bp was used for paired-end sequencing on an Illumina MiSeq platform at the New England Biolabs Ltd. Beijing, China. The raw reads generated from amplicon sequencing were submitted to the Sequence Read Archive of the NCBI (https://trace.ncbi.nlm.nih.gov/Traces/sra/) under the bioProject PRJNA755433, and biosample accessions from SAMN20822645 to SAMN20822648 for soil bacteria, and SAMN20822649 to SAMN20822652 for the fungi.

\section{Statistical analysis and bioinformatics}

$$
\text { Data obtained from plant characteristics and soil physicochemical properties were analyzed }
$$
using the analysis of variance (ANOVA), and the means obtained were separated using Tukey's test at $p<0.05$. 
et al., 2019) was used to classify raw sequences according to the specific barcode assigned to each

sample. The original DNA segments were combined with the Paired-end reads (PERs), using

FLASH (Baltimore, MD, USA) (Magoč \& Salzberg, 2011). PERs were designed for each sample

according to the particular barcodes connected with DNA fragments. UPARSE-OTU reference

algorithm was used to analyze the sequences with the UPARSE software package (CA, USA).

Truncation and removal of chimeric sequences were done using the UCHIME algorithm. It was

ensured that the average quality score remained above 33 with regards to the $50 \mathrm{bp}$ sliding window

when calculating the truncation thresholds. The clean tags obtained were clustered to generate

operational taxonomic units (OTUs) at a 97\% similarity. The taxonomic identities of the soil

microbial communities were checked using the Silva database (Release 138, http://www.arb-

silva.de). The diversity and composition of the bacterial and fungal communities under different

treatments were determined based on the instructions Caporaso et al. (2010). The Chaol and ACE

(species abundance), as well as the Shannon and Simpson indices (community diversity), were

used to estimate the fungal and bacterial alpha diversity (within samples). Krona charts were used

to show the abundances of each bacterial and fungal taxa graphically. For Beta diversity, R

(Version 3.3.1) was used to visualize the similarity distance using Principal Coordinate Analysis

(PCoA). Selected soil physicochemical properties were used to establish the identity and the

\section{Results}


224 Soil physicochemical characteristics

225 All the treatments containing FM, irrespective of its proportion, had significantly higher

226 values $(p<0.05)$ of the measured soil chemical properties. There was no significant difference in

$227 \mathrm{NH}_{4}^{+}$concentration among the FM2 and FM3. However, FM1 had a significantly higher $\mathrm{NH}_{4}^{+}$

228 concentration among all the treatments evaluated. $\mathrm{NO}_{3}{ }^{-}$had lower values in the $\mathrm{FM}$ treatments

229 when compared to the control (CK) (Table 1). While FM increased the soils' $\mathrm{pH}$ relative to CK,

230 there was no significant change in the soil $\mathrm{pH}$ among the FM treatments. Also, the highest AK,

231 EC, TN, TON, and TOC values were obtained in FM3. Also, the AK, TOC, and TON values were

232 significantly highest and statistically similar among FM2 and FM3 treatments. Additionally, the

233 available P content was statistically higher in the FM treatments compared to the CK, although it

234 was highest in value in the d FM2 relative.

\section{Soil enzyme activity}

The influence of FM proportion on the soil enzyme activity: cellulase, phosphatase, urease, and $\beta$-Glucosidase is presented in Figs 1 A-D. Our observations showed that there was no significant $(p<0.05)$ effect of FM rates on cellulase activity (Fig 1A). However, the control treatment had a significantly higher cellulase activity than the FM1 and FM2 while being statistically similar to FM3. On the other hand, phosphatase, urease, and $\beta$-Glucosidase enzymes were stimulated by FM relative to the control. Among the FM proportions, FM3 gave the highest $(p<0.05)$ activity of phosphatase and urease (Fig 1B and C). While there was no significant difference in the activity of $\beta$-Glucosidase among the FM proportions evaluated, its activity was 
244 higher in the FM amendments than the control (Fig 1D).

245 Sugarcane agronomic characteristics

246

247

248

249

250

251

252

253

254

255

256

257

258

259

260

261

262

The application of FM, irrespective of its proportion, significantly increased the plant height, number of tillers, and plant stem diameter compared to the control treatment (Figs 2A, D, and E). The use of FM1 gave the significantly highest $(p<0.05)$ plant height, among other FM treatments. Similarly, FM1, while statistically similar $(p<0.05)$ to other FM treatments, gave higher values for the number of tillers (Fig 2D) and plant diameter (Fig 2E). However, FM treatments had no significant difference $(p<0.05)$ when compared to the control with respect to the leaves' chlorophyll content (Fig 2B) and the number of leaves (Fig 2C). There was no statistical difference in the leaves' chlorophyll content and the number of leaves among the FM treatments, despite the observed reduction in FM2 and FM3.

\section{Relative abundance of dominant microbial phyla in filtered mud amended soil}

The relative abundances of the top 10 soil bacterial and fungal phyla as influenced by the different FM:soil ratios are presented in Figs 3A and B. The Proteobacteria was dominant in the soil, and their relative abundance ranged from $42.54-50.76 \%$ and decreased with an increasing rate of FM. The Actinobacteria (14.74-25.59\%), which were the second most abundant bacterial phyla, increased in the FM treated soil relative to the control. Its highest proportion was obtained in FM3. These were followed by the Acidobacteria (4.51-11.48\%), which decreased in the FM treated soils. Among the phyla observed, Bacteroidetes (3.65-6.03\%), Chloroflexi (2.7-4.71\%), 
263 Planctomycetes (1.16-3.49\%), and Candidatus Saccharibacteria (0.43-2.83\%) increased in the

264 FM treated soils compared to the control. However, the relative abundances of the

265 Gemmatimonadetes (3.44-5.9\%) and Firmicutes (1.52-2.27\%) also reduced in the FM treated

266 soils compared to the control (Fig 3A). Similarly, there was an alteration in the relative abundances

267 of fungal phyla after the FM application (Fig 3B). The most dominant fungal phyla observed were

268 the Ascomycota (29.73-59.13\%), whose relative abundance was reduced in the FM treated soils

269 compared to the CK treatment. Its lowest abundance was observed in FM2, among the FM-treated

270 soils.

The Alphaproteobacteria class dominated the Proteobacteria class and was reduced in FM

treatments relative to the control. Its lowest proportion was observed in FM3 (Fig 4A). However,

there was a notable increase in the relative abundance of the Betaproteobacteria and

Gammaproteobacteria, which comprise members that are ammonium oxidizing due to FM. This

was confirmed in the increase in the ammonium oxidizing genera, Devoisa, Luteimonas, and

Povalibacter in the FM treatments (Fig S1). Similarly, bacterial class distribution revealed the

abundance of Actinobacteria, which contains N-cycling genera, such as the Nocardioides in FM

treatments (Fig S1), with FM 3 having the highest relative abundance (Fig 4A).

Gemmatimonadetes and Sphingobacteriia reduced in abundance in FM treatments relative to the

control. The FM amendment suppressed the abundance of the fungal class Sordariomycetes and

Eurotiomycetes (Fig 4B). While the Sordariomycetes had their highest proportion in the FM2 
284 in FM1 and FM2. The Saccharomycetes were increased under FM, with its highest proportion in 285 FM2.

286 Alpha and beta diversity of soil bacterial and fungal communities

Across the diversity indices evaluated, the FM amended treatments significantly reduced difference $(p<0.05)$ was observed in the fungal community richness indices, ACE (Fig 5E), Chao1 showed that FM2 had the least fungal diversity, while FM1 gave the highest diversity (Fig 5H).

$6 \mathrm{~A}$ and $\mathrm{B})$ showed the shift of bacterial and fungal community composition under different and $\mathrm{B})$. 
303

304

305 in the PCoA.

306

307

308

309

310

311

312

313

314

315

316

317

318

319

320

communities Rozellomycota.

\section{Discussion}

treatments (Fig 6B). It was, however, observed that the control treatment was distinct from FM treatments (Fig 6B). Distinct clustering of fungal communities in FM2 and FM3 was also observed

\section{Relationship between soil properties and the distribution of bacterial and fungal}

Redundancy analysis (RDA) was performed to explore the influence of soil variables on the relative abundance and community composition of bacterial and fungal phyla (Fig 7A and B). It was observed that RDA1 and 2 accounted for $67.07 \%$ and $12.32 \%$, respectively, for the changes in the bacterial phyla composition, while RDA1 and 2 accounted for $42.14 \%$ and $11.18 \%$, respectively, for the differences in fungal community composition (Fig 7B). The content of soil AP, $\mathrm{pH}, \mathrm{TOC}$, and TON positively influenced the abundance of Bacteroidetes and Chloroflexi, while the availability of $\mathrm{NH}_{4}^{+}$and TON correlated with the relative abundance of the Actinobacteria. The concentration of soil $\mathrm{NO}_{3}{ }^{-}$showed a close association with Acidobacteria and Gemmatimonadetes. Similarly, the availability of $\mathrm{NO}_{3}^{-}$influenced the abundance of Ascomycota (Fig 7B). Likewise, TN, TON, pH, $\mathrm{C} / \mathrm{N}$ ratio, and AP were the significant factors that influenced the abundance of Basidiomycota. The TOC of the treatments influenced the abundance of 

in the chemical properties of the soil due to the addition of FM could be attributed to its ability to retain soil nutrients and ensuring their slow release, in addition to its high nutritional contents. This was evident in the increase in plant height, number of tillers, and plant diameter under FM, especially in FM1. The observed increase in soil chemical properties due to FM is consistent with the finding of Tayyab et al. (2018) who documented that the application of sugarcane straw to the soil improved its physicochemical properties. Therefore, the bioavailability of nutrients, especially the slow release of $\mathrm{N}$, could be responsible for the improvement in some agronomic properties of sugarcane as observed in the FM treatments. Such improvement in wheat growth characteristics due to FM has been previously reported by Khan et al. (2012). Several reports have also documented a positive effect of FM on productivity parameters and yield of several crops (Singh characteristics of sugarcane as observed could also be attributed to the significant increase in soil nutrients, which were enhanced by the additional nutrient content of FM, and slow release of $\mathrm{N}$. The application of organic amendments to the soil such as compost, cover crops, and manure has been shown to enrich soils with slowly released available mineral nitrogen for plants use (Bulluck et al., 2002; Cesarano et al., 2017; Ibrahim et al., 2020b). Therefore, as an organic amendment derived from sugarcane, the use of FM does not only improves soil physical and chemical properties for sugarcane growth (Rakkiyappan et al., 2001) but also serves to return some of the 
342 cycling. Among the FM treatments, FM1 contained a higher amount of $\mathrm{NH}_{4}^{+}$, which is the most

343 needed $\mathrm{N}$ form for sugarcane growth. Unlike most other crops, evidence has shown that sugarcane

344 has a preferential uptake of ammonium than other forms of N (Boschiero et al., 2018). Although

$345 \mathrm{NH}_{4}$ concentration was similar in the $\mathrm{CK}, \mathrm{FM} 2$, and FM3, the lower TN in CK suggests that higher

346 mineralization of the soil's native $\mathrm{N}$ May have occurred, which may result in inorganic $\mathrm{N}$ losses if

347 a lower uptake accompanied by leaching losses occurs. The reduction in $\mathrm{NO}_{3}{ }^{-}$in $\mathrm{FM}$ treatments

348 compared to the CK may have served to ensure a slow release to meet up the plant's needs. Organic

349 amendments, including FM, are also known to immobilize inorganic $\mathrm{N}$ and ensure its slow release,

350 thereby avoiding losses by leaching, runoff, or volatilization (Kumar et al., 2017; Ibrahim et al., 351 2020b).

Soil enzyme activities are essential indicators of soil fertility and are actively involved in nutrient cycling (Nannipieri et al., 2012). The increase in $\mathrm{C}$ and $\mathrm{N}$ cycling enzyme activities with an increase in FM rates showed that FM could be beneficial in $\mathrm{C}$ and $\mathrm{N}$ turnover and soil fertility. This was evident in the improved soil nutrient contents and growth of the sugarcane plant in the FM-treated soils. The increase of urease activity with increasing FM rates as observed agrees with

357 the report that its activity increased after organic fertilization (Sardans et al., 2008; Chen et al., 358 2017). This may be linked to the increase in bacterial taxa linked to N-cycling in these treatments 359 (Fig 3A). Urease is required for the hydrolysis of urea (Ibrahim et al., 2020a). This was important 360 for the mineralization of $\mathrm{N}$ present in the FM treatments for crop use. The increase in urease was 361 associated with a slow release and availability of inorganic $\mathrm{N}$ in the FM treatments. Soil cellulase 
362 is responsible for the breaking down of cellulose (Averill and Hawkes, 2016). However, the

363 reduction in its activity in FM treatments, especially in FM1 and FM2, could be linked to its

364 inhibition of cellulase activity by reducing the abundance of microorganisms that act on cellulose,

365 as observed in the reduction in the Ascomycota, which contain a wide range of cellulase degrading

366 members (Fig 3B). In addition, the increase in $\beta$-glucosidase in all the FM amended soil samples

367 might be due to a rise in the labile organic $\mathrm{C}$ due to the increase in the total organic $\mathrm{C}$ provided by

368 FM needed for its activity, as previously reported (Simarani et al., 2018). $\beta$-glucosidase is an

369 extracellular enzyme that helps in the mineralization of carbon (Brookes et al., 2008). Therefore,

370 a higher amount of this enzyme in the FM treatments would be associated with the mineralization

371 of organic $\mathrm{C}$ in the amendment and the associated availability of its mineralized form for other soil

372 microbes involved in nutrient cycling.

The reactions of the soil microbial community to agricultural management are extremely complicated. Environmental factors such as moisture and soil temperature, which are often variably influenced by organic amendments, can regulate the diversity and community composition of soil organisms (Carey et al., 2015; Vickers, 2017). As an organic amendment, FM

377 could effectively increase soil $\mathrm{pH}$, drainage and stimulate soil microbial activities (Tandon et al., 1995; Yang et al., 2013). Some Proteobacteria members like the Betaproteobacteria are referred

379 to as copiotrophic, and thrive in an environmental condition with a high $\mathrm{C}$ content and other 380 nutrients (Feirer et al., 2007; Yang et al., 2019; Ibrahim et al., 2020a). This could explain their 381 increased relative abundance in the FM treatments compared to the control (CK). The 
382 Acidobacteria had a higher relative abundance in the CK compared to FM-treated soils. This 383 phylum is often found in low fertility soil, which explains its abundance in the CK treatment.

384 Similar to our observations, Acidobacteria had a negative correlation with soil $\mathrm{pH}$, as previously reported by Lauber et al. (2009) and Rousk et al. (2010). Generally, Acidobacteria is referred to as Oligotrophs that grow successfully in natural cropland ecosystems (Pershina et al., 2015) and have been reported to contribute to the degradation of recalcitrant organic compounds (Fierer et al., 2012). Similarly, Bryant and Frigaard (2006) considered the Chloroflexi taxa as anoxygenic phototrophs, which play an essential role in the process of nitrification. However, the lower nitrification in the FM-based treatments where they were slightly increased may indicate that their taxonomic members present were not actively involved in the nitrification process. treatments, especially in FM3. Reports have also shown Actinobacteria to be prevalent in soils amended with press mud (filtered mud) (Yang et al., 2013). However, some contrary reports have shown that the typical soil has a higher relative abundance of Actinobacteria than organically amended soils (Francioli et al., 2016; Das et al., 2017). Moreover, many members of the Actinobacteria phyla play important roles in N mineralization (Fallah et al., 2021; Ibrahim et al., 2020b), organic material decomposition like cellulose and chitin (Ibrahim et al., 2021), and helps in agrochemical degradation (Bonanomi et al., 2016). Additionally, the Actinobacterial taxa play a vital role in the transportation of soil phosphorous and biological control and have been referred 
403 abundance of the phylum Firmicutes was observed to increase with increasing FM proportions.

404 This bacterial phylum flourishes in high C-rich soil and plays a crucial role in the degradation of 405 complex organic materials (Pershina et al., 2015; Tayyab et al., 2018), and is involved in the 406 depolymerization of lignin (Wu \& He, 2013). Filtered mud, which contains a proportion of the 407 original sugarcane biomass, contains about 9\% lignin (Saleh-e-In et al., 2012). This may explain 408 the increase in abundance of the Firmicutes with increasing organic C sources due to higher FM proportions. The Alphaproteobacteria, which are non-nitrifying, survive on a small amount of soil nutrients and are the most dominant class of Proteobacteria in soils (Yang et al., 2013). This could explain their abundance in the CK treatment compared to the FM treated soil with higher nutrients.

The Betaproteobacteria and Gammaproteobacteria, which contained the ammonium-oxidizing genera, Luteimonas and Povalibacter, were stimulated in the FM compared to the control treatments. Their presence was important to ensure gradual nitrification and the slow release of inorganic $\mathrm{N}$ from the abundant total $\mathrm{N}$ in the FM for plant use over time. Luteimonas, for example, isolated from rhizosphere soils was found to play important roles in $\mathrm{N}$ cycling (Cheng et al., 2016). abundance across the treatments evaluated. Its reduction in FM compared to the control was associated with a reduction in its class members, Eurotiomycetes and Spizellomycetes. The reduction may be attributed to the decrease in the cellulase activity in FM treatments, as cellulase enzyme activity has often been associated with an abundance of fungi involved in the degradation 
424 in the agroecosystems. The abundance of the fungal class Dothideomycetes, a member of the

425 Ascomycota phylum in FM treatments, signified that they were the taxa that are actively stimulated

426 under FM amendment for the degradation of organic matter introduced in the FM amendment.

427 In addition, the observed reduction in bacterial species richness and diversity in the FM

428 treatments compared to the control treatment may have resulted from the stimulation and

429 dominance of organisms involved in nutrient cycling, which outcompeted other organisms. The

430 dominance of organisms involved in specialized functions in organic amended soils could increase

431 their abundance and hence, reduce the diversity of other outcompeted organisms (Ibrahim et al.,

432 2020b). The higher microbial diversity in the CK where there was lower nutrient composition

433 could be associated with a higher community of oligotrophs (organisms that occasionally exist in

434 soil with a low level of nutrients) (Feirer et al., 2007). The clustering pattern of the FM amended

435 treatments may indicate that there was an increase in soil nutrients, hence, a conducive

436 environment for the dominance of bacterial and fungal communities involved in nutrient cycling,

437 as observed in the increase in some nutrient cycling enzyme activities. This was evident in the

438 enrichment of the Actinobacteria, Gammaproteobacteria, Betaproteobacteria, which contains

439 general that are actively involved in $\mathrm{N}$-cycling, as well as the organic $\mathrm{C}$ decomposing

440 Dothideomycetes.

441 Microbial community composition shifts are regulated by soil physicochemical properties

442 (Zhalnina et al., 2015; Fallah et al., 2021). As observed in our experiment, soil pH serves as one

443 of the most important driving factors that regulate microbial diversity (Bartram et al., 2014; 
444 Zhalnina et al., 2015). Moreover, studies conducted by Lauber et al. (2009) and Shen et al. (2013)

445 observed that soil $\mathrm{pH}$ in the natural environmental system is the most crucial factor in determining

446 soil microbial communities' structure as it influences the availability of nutrients in the soil.

447 Similarly, the nutritional composition of the soil is innately connected with the shifts in microbial

448 distribution (Zhang et al., 2019; Ibrahim et al., 2020a,b). This was evident in our study as the effect

449 of FM on soil nutritional properties was among the major factors the regulated the distribution of

450 soil microbial populations.

\section{Conclusion}

The evaluation of different FM:soil proportions on soil chemical properties, sugarcane growth,

and the changes in the functional abundance of soil bacterial and fungal taxa was carried out. The

use of FM improved the soil's chemical properties and the slow-release of $\mathrm{NO}_{3}{ }^{-}$. Specifically, FM1

increased the concentration of $\mathrm{NH}_{4}{ }^{+}-\mathrm{N}$, the $\mathrm{N}$ fraction preferably taken up by sugarcane, which

was associated with an increase in the plant height, and more improved growth properties, among

other treatments. An increase in the proportion of FM also increased the activity of soil nutrient

cycling enzymes. The use of FM reduced the diversity of soil bacteria while having an insignificant

effect on fungal diversity. Its use stimulated the abundance of the bacterial phyla Actinobacteria,

Bacteriodates, Acidobacteria, and Chloroflexi, which are beneficial organisms, and the fungal

phylum Ascomycota involved in degrading the lignocellulose complex. The distribution of the soil 
465 Future studies may consider the evaluation of the effects of FM on plant nutrients uptake,

466 especially $\mathrm{N}$, using isotopic tracer techniques in different soil types and under varied conditions

467 Acknowledgment

468 We appreciate the kind contributions of the team members of the Key Laboratory of Sugarcane

469 Biology and Genetic Breeding, Fujian Agriculture and Forestry University, Fuzhou, China, for

470 their immense contributions to the success of this research.

\section{References}

472 Averill C, Hawkes CV. 2016. Ectomycorrhizal fungi slow soil carbon cycling. Ecology Letters.

$473 \quad 10.1111 /$ ele.12631

474 Azeem B, ku shaari KZ, Man Z, Basit A, Trinh T. 2014. Review on Materials \& Methods to

475 Produce Controlled Release Coated Urea Fertilizer. Journal of Continuous Release, 181.

476 https://doi.org/10.1016/j.jconrel.2014.02.020.

477 Bartram AK, Jiang X, Lynch MD, Masella AP, Nicol GW, Dushoff J, Neufeld JD. 2014. Exploring

478 links between $\mathrm{pH}$ and bacterial community composition in soils from the Craibstone Experimental

479 Farm. FEMS Microbiology and Ecology, 87(2):403-15. https://doi.org/10.1111/1574-6941.12231

480 Bei S, Zhang Y, Li T, Christie P, Li X, Zhang J. 2018. Response of the soil microbial community

481 to different fertilizer inputs in a wheat-maize rotation on a calcareous soil. Agriculture, Ecosystem

482 and Environment, 260:58-69. https://doi.org/10.1016/j.agee.2018.03.014 
483 Bolyen E, Rideout JR, Dillon MR, Bokulich NA, Abnet CC, Al-Ghalith GA, Alexander H, Alm 484 EJ, Arumugam M, Asnicar F, Bai Y, Bisanz JE, Bittinger K, Brejnrod A, Brislawn CJ, Brown CT, 485 Callahan BJ, Caraballo-Rodríguez AM, Chase J, Cope EK, Da Silva R, Diener C, Dorrestein PC,

JM, Gibbons SM, Gibson DL, Gonzalez A, Gorlick K, Guo J, Hillmann B, Holmes S, Holste H,

Huttenhower C, Huttley GA, Janssen S, Jarmusch AK, Jiang L, Kaehler BD, Kang KB, Keefe CR,

Keim P, Kelley ST, Knights D, Koester I, Kosciolek T, Kreps J, Langille MGI, Lee J, Ley R, Liu

YX, Loftfield E, Lozupone C, Maher M, Marotz C, Martin BD, McDonald D, McIver LJ, Melnik

AV, Metcalf JL, Morgan SC, Morton JT, Naimey AT, Navas-Molina JA, Nothias LF, Orchanian

SB, Pearson T, Peoples SL, Petras D, Preuss ML, Pruesse E, Rasmussen LB, Rivers A, Robeson

MS 2nd, Rosenthal P, Segata N, Shaffer M, Shiffer A, Sinha R, Song SJ, Spear JR, Swafford AD,

Thompson LR, Torres PJ, Trinh P, Tripathi A, Turnbaugh PJ, Ul-Hasan S, van der Hooft JJJ, 495

Vargas F, Vázquez-Baeza Y, Vogtmann E, von Hippel M, Walters W, Wan Y, Wang M, Warren 496

J, Weber KC, Williamson CHD, Willis AD, Xu ZZ, Zaneveld JR, Zhang Y, Zhu Q, Knight R,

Caporaso JG. 2019. Reproducible, interactive, scalable and extensible microbiome data science

using QIIME 2. National Biotechnology, 37(9):1091. https://doi.org/10.1038/s41587-019-0209-9. 
502 Bonilla N, Gutiérrez-Barranquero JA, Vicente AD, Cazorla FM. 2012. Enhancing soil quality and 503 plant health through suppressive organic amendments. Diversity 4(4):475-91. 504 https://doi.org/10.3390/d4040475.

505 Boschiero BN, Mariano E, Trivelin PCO. 2018. "Preferential" ammonium uptake by sugarcane 506 does not increase the ${ }^{15} \mathrm{~N}$ recovery of fertilizer sources. Plant Soil 429:253-269. 507 https://doi.org/10.1007/s11104-018-3672-z

508 Brookes P, Cayuela ML, Contin M, De Nobili M, Kemmitt S, Mondini C. 2008. The mineralisation 509 of fresh and humified soil organic matter by the soil microbial biomass. Waste Management, 510 28(4):716-22. https://doi.org/10.1016/j.wasman.2007.09.015

511 Bryant DA, Frigaard N-U. 2006. Prokaryotic photosynthesis and phototrophy illuminated. Trends 512 in Microbiology, 14(11):488-96. https://doi.org/10.1016/j.tim.2006.09.001

513 Bulluck L, Brosius M, Evanylo G, Ristaino J. 2002. Organic and synthetic fertility amendments 514 influence soil microbial, physical and chemical properties on organic and conventional farms. 515 Applied Soil Ecology. 19(2):147-60. https://doi.org/10.1016/S0929-1393(01)00187-1

516 Caporaso JG, Kuczynski J, Stombaugh J, Bittinger K, Bushman FD, Costello EK, Fierer N, Pena 517 AG, Goodrich JK, Gordon JI. 2010. QIIME allows analysis of high-throughput community 518 sequencing data. Nature Methods, 7(5):335-6. https://doi.org/10.1038/nmeth.f.303.

519 Carey CJ, Beman JM, Eviner VT, Malmstrom CM, Hart SC. 2015. Soil microbial community 520 structure is unaltered by plant invasion, vegetation clipping, and nitrogen fertilization in 
521 experimental semi-arid grasslands. Frontiers $\quad$ Microbiology, 466.

522 https://doi.org/10.3389/fmicb.2015.00466

523 Cesarano G, De Filippis F, La Storia A, Scala F, Bonanomi G. 2017. Organic amendment type

524 and application frequency affect crop yields, soil fertility and microbiome composition. Applied

525 Soil Ecology, 120:254-64. https://doi.org/10.1016/j.apsoil.2017.08.017.

526 Chen Y, Xin L, Liu J, Yuan M, Liu S, Jiang W, Chen J. 2017. Changes in bacterial community of 527 soil induced by long-term straw returning. Scientia Agriculturae, 74(5):349-56.

528 https://doi.org/10.1590/1678-992x-2016-0025

529 Cheng J, Zhang MY, Wang WX, Manikprabhu D, Salam N, Zhang TY, Wu YY, Li WJ, Zhang

530 YX. 2016. Luteimonas notoginsengisoli sp. nov., isolated from rhizosphere soil. Int Journal of

531 Systemic and Evolutionary Microbiology. 66:946-950

532 Dai H, Chen Y, Yang X, Cui J, Sui P, 2017. The effect of different organic materials amendment 533 on soil bacteria communities in barren sandy loam soil. Environmental Science and Pollution 534 Research, 24(30):24019-28. https://doi.org/10.1007/s11356-017-0031-1.

535 Das S, Jeong ST, Das S, Kim PJ. 2017. Composted cattle manure increases microbial activity and 536 soil fertility more than composted swine manure in a submerged rice paddy. Frontiers in 537 Microbiology, 8:1702. https://doi.org/10.3389/fmicb.2017.01702.

538 Deng SP, Tabatabai MA. 1994. Cellulase activity in soils. Soil Biology and Biochemistry. 539 26(10):1347-1354. https://doi.org/10.1016/0038-0717(94)90216-X 
540 Fallah N, Yang Z, Tayyab M, Zhang C, Abubakar AY, Lin Z, Pang Z, Zhang H. 2021. Depth-

541 dependent influence of biochar application on the abundance and community structure of 542 diazotrophic under sugarcane growth. PLoS ONE 16(7):e0253970.

543 https://doi.org/10.1371/journal.pone.0253970

544 Fierer N, Bradford MA, Jackson RB. 2007. Toward an ecological classification of soil bacteria.

545 Ecology, 88(6):1354-64. https://doi.org/10.1038/ismej.2011.159

546 Fierer N, Lauber CL, Ramirez KS, Zaneveld J, Bradford MA, Knight R. 2012. Comparative

547 metagenomic, phylogenetic and physiological analyses of soil microbial communities across

548 nitrogen gradients. The ISME Journal, 6(5):1007-17. https://doi.org/10.1038/ismej.2011.159

549 Francioli D, Schulz E, Lentendu G, Wubet T, Buscot F, Reitz T. 2016. Mineral vs. organic

550 amendments: microbial community structure, activity and abundance of agriculturally relevant

551 microbes are driven by long-term fertilization strategies. Frontiers Microbiology, 7:1446.

552 https://doi.org/10.3389/fmicb.2016.01446

553 Ibrahim M.M, Hu K, Tong C, Xing S, Zou S, Mao Y. 2020b. De-ashed biochar enhances nitrogen

554 retention in manured soil and changes soil microbial dynamics. Geoderma, 378:114589,

555 https://doi.org/10.1016/j.geoderma.2020.114589.

556 Ibrahim MM, Tong C, Hu K, Zhou B, Xing S, Mao Y. 2020a. Biochar-fertilizer interaction

557 modifies N-sorption, enzyme activities and microbial functional abundance regulating nitrogen 
558 retention in rhizosphere soil. Science of the Total Environment, 739:140065.

559 https://doi.org/10.1016/j.scitotenv.2020.140065

560 Ibrahim MM, Zhang H, Guo L, Chen Y, Heiling M, Zhou B, Mao Y. 2021. Biochar interaction

561 with chemical fertilizer regulates soil organic carbon mineralization and the abundance of key C-

562 cycling-related bacteria in rhizosphere soil. European Journal of Soil Biology 106:103350. https:/

563 /doi.org/10.1016/j.ejsobi.2021.103350.

564 Jamil M, Qasim M, Zia MS. 2008. 'Utilisation of pressmud as organic amendment to improve

565 physico-chemical characteristics of calcareous soil under two legume crops. Journal-Chemical

566 Society of Pakistan. 30(4):577-584.

567 Joshi N, Sharma S, Kangri G. 2010. Physico-chemical characterization of sulphidation press mud

568 composted press mud and vermicomposted pressmud. Reports and Opinion, 2(3):79-82.

569 Kaur K, Kapoor KK, Gupta AP. 2005. Impact of organic manures with and without mineral

570 fertilizers on soil chemical and biological properties under tropical conditions. Journal of Plant

571 Nutrition and Soil Science, 168(1):117-22. https://doi.org/10.1002/jpln.200421442.

572 Khalil F, Yueyu X, Naiyan X, Di L, Tayyab M, Hengbo W, Islam W, Rauf S, Pinghua C. 2018.

573 Genome characterization of Sugarcane Yellow Leaf Virus with special reference to RNAi based

574 molecular breeding. Microbial $\quad$ Pathogens, $\quad$ 120:187-197.

575 https://doi.org/10.1016/j.micpath.2018.05.001 
576 Khan MJ, Khan MQ, Zia MS. 2012. Sugar industry press mud as alternate organic fertiliser source.

577 International Journal of Environmental Waste Management, 9(1-2):41-55.

578 https://doi.org/10.1504/IJEWM.2012.044159.

579 Kumar B, Kumar S, Prakash D, Singh SK, Mishra M, Jain PK, Lal RB, Sharma CS, Mukherjee

580 DP. 2011. A study on sugar mill pressmud compost for some heavy metal content and their bio-

581 availability. Asian Journal of Plant Science Research, 1:115-22.

582 Kumar S, Meena, RS, Jinger D, Jatav HS, Banjara T. 2017. Use of pressmud compost for 583 improving crop productivity and soil health. International Journal of Chemical Studies. 5(2):384584389.

585 Langarica-Fuentes A, Zafar U, Heyworth A, Brown T, Fox G, Robson GD. 2014. Fungal 586 succession in an in-vessel composting system characterized using pyrosequencing. FEMS 587 Microbiology and Ecology, 88(2):296-308. https://doi.org/10.1111/1574-6941.12293

588 Lauber CL, Hamady M, Knight R, Fierer N. 2009. Pyrosequencing-based assessment of soil pH 589 as a predictor of soil bacterial community structure at the continental scale. Applied Environmental 590 Microbiology, 75(15):5111-20. https://doi.org/10.1128/AEM.00335-09

591 Lienhard P, Terrat S, Prévost-Bouré NC, Nowak V, Régnier T, Sayphoummie S, Panyasiri K, 592 Tivet F, Mathieu O, Levêque J, Maron PA, Ranjard L. 2014. Pyrosequencing evidences the impact 593 of cropping on soil bacterial and fungal diversity in Laos tropical grassland. Agronomy for 594 Sustainable Development, 34(2):525-33. 
595 Liu X, Zhang Y, Han W, Tang A, Shen J, Cui Z, Vitousek P, Erisman W, Goulding K, Christie P. 596 2013. Enhanced nitrogen deposition over China. Nature, 494(7438):459-62. 597 https://doi.org/10.1038/nature11917.

598 Magoč T, Salzberg SL. 2011. FLASH: fast length adjustment of short reads to improve genome 599 assemblies. Bioinformatics, 27(21):2957-63.

600 https://doi.org/10.1093\%2Fbioinformatics\%2Fbtr507.

601 Mander C, Wakelin S, Young S, Condron L, O'Callaghan M. 2012. Incidence and diversity of 602 phosphate-solubilising bacteria are linked to phosphorus status in grassland soils. Soil Biology and 603 Biochemistry. 44(1):93-101.

604 Melero S, Porras JCR, Herencia JF, Madejon E. 2006. Chemical and biochemical properties in a 605 silty loam soil under conventional and organic management. Soil Tillage Research, 90(1-2):162606 70. https://doi.org/10.1016/j.still.2005.08.016

607 Michelsen CF, Pedas P, Glaring MA, Schjoerring JK, Stougaard P. 2014. Bacterial diversity in 608 Greenlandic soils as affected by potato cropping and inorganic versus organic fertilization. Polar 609 Biology, 37(1):61-71. https://doi.org/10.1007/s00300-013-1410-9.

610 Nannipieri P, Giagnoni L, Renella G, Puglisi E, Ceccanti B, Masciandaro G, Fornasier F, 611 Moscatelli MC, Marinari S. 2012. Soil enzymology: classical and molecular approaches. Biology 612 and Fertility of Soils. 48(7):743-62. https://doi.org/10.1007/s00374-012-0723-0 
613 Pansu M, Gautheyrou J. 2007. Handbook of soil analysis: mineralogical, organic and inorganic 614 methods: Springer Science \& Business Media. https://doi.org/10.1017/S0014479707005042

615 Pershina E, Valkonen J, Kurki P, Ivanova E, Chirak E, Korvigo I, Provorov N, Andronov E. 2015.

616 Comparative analysis of prokaryotic communities associated with organic and conventional

617 farming systems. PLoS One. 10(12):e0145072. https://doi.org/10.1371/journal.pone.0145072

618 Rakkiyappan P, Thangavelu S, Malathi R, Radhamani R. 2001. Effect of biocompost and enriched 619 press mud on sugarcane yield and quality. Sugar Technology. 3:92-96.

620 Rivera-Becerril F, van Tuinen D, Chatagnier O, Rouard N, Béguet J, Kuszala C, Soulas G,

621 Gianinazzi-Pearson V, Martin-Laurent F. 2017. Impact of a pesticide cocktail (fenhexamid, folpel, 622 deltamethrin) on the abundance of Glomeromycota in two agricultural soils. Science of the Total 623 Environment, 577:84-93. https://doi.org/10.1016/j.scitotenv.2016.10.098.

624 Rousk J, Bååth E, Brookes PC, Lauber CL, Lozupone C, Caporaso JG, Knight R, Fierer N. 2010. 625 Soil bacterial and fungal communities across a $\mathrm{pH}$ gradient in an arable soil. The ISME Journal. 626 4(10):1340-51. https://doi.org/10.1038/ismej.2010.58

627 Saleh-e-In MM, Yeasmin S, Paul BK, Ahsan M, Rahman MZ, Roy SK. 2012. Chemical Studies 628 on Press Mud: A Sugar Industries Waste in Bangladesh. Sugar Technology, 14(2):109-18. 629 https://doi.org/10.1007/s12355-012-0139-z. 
630 Sardans J, Peñuelas J, Estiarte M. 2008. Changes in soil enzymes related to C and N cycle and in 631 soil $\mathrm{C}$ and $\mathrm{N}$ content under prolonged warming and drought in a Mediterranean shrubland. Applied 632 Soil Ecology, 39(2):223-35. https://doi.org/10.1016/J.APSOIL.2007.12.011

633 Shen C, Xiong J, Zhang H, Feng Y, Lin X, Li X, Liang W, Chu H. 2013. Soil pH drives the spatial 634 distribution of bacterial communities along elevation on Changbai Mountain. Soil Biology and 635 Biochemistry, 57:204-11. https://doi.org/10.1016/j.soilbio.2012.07.013

636 Shendure J, Ji H. 2008. Next-generation DNA sequencing. Nature biotechnology. 26(10):1135637 45. https://doi.org/10.1038/nbt1486

638 Simarani K, Azlan Halmi MF, Abdullah R. 2018. Short-term effects of biochar amendment on soil 639 microbial community in humid tropics. Archives of Agronomy and Soil Science, 64(13):1847-60. 640 https://doi.org/10.1080/03650340.2018.1464149

641 Singh B, Singh Y, Khind C, Ladha J, Gupta R. 2003. Managing pressmud cake for nitrogen and 642 phosphorus nutrition of crops in a rice-wheat rotation. International Rice Research Notes, 28(1):1-.

643 Smit E, Leeflang P, Glandorf B, Van Elsas JD, Wernars K. 1999. Analysis of fungal diversity in 644 the wheat rhizosphere by sequencing of cloned PCR-amplified genes encoding 18S rRNA and 645 temperature gradient gel electrophoresis, Applied Environmental Microbiology, 65(6):2614-21. 646 https://doi.org/10.1128/aem.65.6.2614-2621.1999.

647 Stege PW, Messina GA, Bianchi G, Olsina RA, Raba J. 2010. Determination of $\beta$-glucosidase 648 activity in soils with a bioanalytical sensor modified with multiwalled carbon 
649 nanotubes. Analytical and Bioanalytical Chemistry. 397:1347-1353.

650 https://doi.org/10.1007/s00216-010-3634-7

651 Sun J, Zhang Q, Zhou J, Wei Q. 2014. Pyrosequencing technology reveals the impact of different

652 manure doses on the bacterial community in apple rhizosphere soil. Applied Soil Ecology, 78:28-

653 36. https://doi.org/10.1016/j.apsoil.2014.02.004

654 Tabatabai MA, Bremner JM. 1969. Use of p-nitrophenylphosphate for assay of soil phosphatase

655 activity. Soil Biology and Biochemistry, 1:301-307. https://doi.org/10.1016/0038-0717(69)90012-

6561

657 Tandon HLS. 1995. Waste recycling in agriculture-an introduction. Recycling of crop, animal, 658 human and industrial wastes in agriculture. Fertilizer Development and Consultation 659 Organization. New Delhi. 1-8.

660 Tayyab M, Islam W, Arafat Y, Pang Z, Zhang C, Lin Y, Waqas M, Lin S, Lin W, Zhang H. 2018.

661 Effect of Sugarcane Straw and Goat Manure on Soil Nutrient Transformation and Bacterial

662 Communities. Sustainability, 10(7):2361. https://doi.org/10.3390/SU10072361.

663 Tayyab M, Islam W, Khalil F, Ziqin P, Caifang Z, Arafat Y, Hui L, Rizwan M, Waheed S, Tarin

664 MWK, Hua Z. 2018. Biochar: An efficient way to manage low water availability in plants. Applied

665 Ecology and Environmental 16:2565-83.

666 https://doi.org/10.15666/AEER/1603_25652583 
667 Tayyab M, Islam W, Lee C, Pang Z, Khalil F, Lin S, Lin W, Zhang H. 2019. Short-term effects of 668 different organic amendments on soil fungal composition. Sustainability, 11(1):198. 669 https://doi.org/10.3390/su11010198.

670 Thorburn PJ, Biggs JS, Palmer J, Meier EA, Verburg K, Skocaj DM. 2017. Prioritizing crop 671 management to increase nitrogen use efficiency in Australian sugarcane crops. Frontiers in Plant 672 Science, 8:1504. https://doi.org/10.3389/fpls.2017.01504.

673 Vickers NJ. 2017. Animal Communication: When I'm Calling You, Will You Answer Too? 674 Current Biology, 27(14):R713-R5. https://doi.org/10.1016/j.cub.2017.05.064

675 Vitousek PM, Naylor R, Crews T, David M, Drinkwater L, Holland E, Johnes P, Katzenberger 676 J, Martinelli L, Matson P. 2009. Nutrient imbalances in agricultural development. Science, 677 324(5934):1519-20. https://doi.org/10.1126/science.1170261.

$678 \mathrm{Wu}$ Y-R, He J. 2013. Characterization of anaerobic consortia coupled lignin depolymerization 679 with biomethane generation. Bioresource Technology, 139:5-12. 680 https://doi.org/10.1016/j.biortech.2013.03.103

681 Yadav DV, 1992. Utilization of press mud cakes in Indian agriculture. Indian Journal of Sugar 682 Technology, 7:1-16. https://doi.org/10.1007/s40093-016-0132-8.

683 Yang SD, Liu JX, Wu J. Tan HW, Li YR. 2013. Effects of Vinasse and Press Mud Application on 684 the Biological Properties of Soils and Productivity of Sugarcane. Sugar Tech 15:152-158. 685 https://doi.org/10.1007/s12355-012-0200-y 
686 Yang W, Wang S, Ni W, Rensing C, Xing S. 2019. Enhanced Cd-Zn-Pb-contaminated soil 687 phytoextraction by Sedum alfredii and the rhizosphere bacterial community structure and function 688 by applying organic amendments. Plant and soil, 1-18 https:// doi.org/10.1007/s11104-019689 04256-X

690 Zhalnina K, Dias R, de Quadros PD, Davis-Richardson A, Camargo FA, Clark IM, McGrath, SP, 691 Hirsch PR, Triplett EW. 2015. Soil pH determines microbial diversity and composition in the park 692 grass experiment. Microbial Ecology, 69(2):395-406. https://doi.org/10.1007/s00248-014-0530-2 693 Zhang M, Muhammad R, Zhang L, Xia H, Cong M, Jiang C. 2019. Investigating the effect of 694 biochar and fertilizer on the composition and function of bacteria in red soil. Applied Soil Ecology, 695 139:107-116. https://doi.org/10.1016/j.apsoil.2019.03.021.

696 Zhang Q, Zhou W, Liang G, Wang X, Sun J, He P, Li L. 2015. Effects of different organic manures 697 on the biochemical and microbial characteristics of albic paddy soil in a short-term experiment. 698 PLoS One, 10(4):e0124096. https://doi.org/10.1371/journal.pone.0124096

699

700

701

702

703 


\section{Table $\mathbf{1}$ (on next page)}

Soil physicochemical properties at sampling

CK (control), FM: Filtered mud, FM1 (FM:soil at 1:4), FM2 (FM:soil at 2:3), FM3 (FM:soil at 3:2);. Means are followed by \pm standard error $(S E)(n=3)$. Letters show significant differences between means ( $p>0.05)$. EC: Electrical conductivity; AK: Available potassium; AP: Available phosphorous; TC: Total carbon; TN: Total nitrogen; TOC: Total organic carbon; TON: Total organic nitrogen. 


\begin{tabular}{|c|c|c|c|c|c|c|c|c|c|c|c|}
\hline Treatment & pH & $\begin{array}{c}\text { EC } \\
\text { dSm-1 }\end{array}$ & $\begin{array}{l}\mathrm{AK} \\
(\mathrm{mg}\end{array}$ & $\begin{array}{l}\text { AP } \\
\text { g) }\end{array}$ & $\begin{array}{l}\text { TC } \\
(\mathrm{g})\end{array}$ & g) & $\begin{array}{l}\text { TOC } \\
(\mathrm{mg}\end{array}$ & $\begin{array}{l}\text { TON } \\
\mathrm{kg})\end{array}$ & $\mathrm{C} / \mathrm{N}$ & $\begin{array}{r}\mathrm{NH}_{4}^{+} \\
\quad(\mathrm{mg}\end{array}$ & $\begin{array}{l}\mathrm{NO}_{3}^{-} \\
/ \mathbf{k g})\end{array}$ \\
\hline $\mathrm{CK}$ & $\begin{array}{c}6.1 \pm \\
0.13 b\end{array}$ & $\begin{array}{c}25.28 \pm \\
1.17 \mathrm{~d}\end{array}$ & $\begin{array}{c}74.3 \pm \\
1.5 \mathrm{c}\end{array}$ & $\begin{array}{l}7.4 \pm \\
0.1 \mathrm{~d}\end{array}$ & $\begin{array}{c}10.3 \pm \\
0.4 \mathrm{c}\end{array}$ & $\begin{array}{c}1.5 \pm \\
0.05 \mathrm{~d}\end{array}$ & $\begin{array}{c}134.7 \pm \\
5.9 \mathrm{c}\end{array}$ & $\begin{array}{c}171.1 \pm \\
13.2 \mathrm{c}\end{array}$ & $\begin{array}{c}7.1 \pm \\
0.06 \mathrm{a}\end{array}$ & $\begin{array}{l}10.2 \pm \\
6.8 \mathrm{~b}\end{array}$ & $\begin{array}{c}16.8 \pm \\
1.1 \mathrm{a}\end{array}$ \\
\hline FM1 & $\begin{array}{c}7.2 \pm \\
0.01 \mathrm{a}\end{array}$ & $\begin{array}{c}209.9 \pm \\
2.58 \mathrm{c}\end{array}$ & $\begin{array}{c}120.2 \pm \\
1.6 b\end{array}$ & $\begin{array}{c}57.0 \pm \\
1.3 \mathrm{~b}\end{array}$ & $\begin{array}{c}25.9 \pm \\
1.2 \mathrm{c}\end{array}$ & $\begin{array}{l}6.3 \pm \\
0.1 \mathrm{c}\end{array}$ & $\begin{array}{c}170.8 \pm \\
7.1 \mathrm{~b}\end{array}$ & $\begin{array}{c}201.7 \pm \\
23.9 b\end{array}$ & $\begin{array}{l}4.1 \pm \\
0.2 b\end{array}$ & $\begin{array}{c}16.6 \pm \\
1.1 \mathrm{a}\end{array}$ & $\begin{array}{c}11.1 \pm \\
0.5 \mathrm{c}\end{array}$ \\
\hline FM2 & $\begin{array}{c}7.2 \pm \\
0.08 \mathrm{a}\end{array}$ & $\begin{array}{c}290.7 \pm \\
5.7 \mathrm{~b}\end{array}$ & $\begin{array}{c}255.7 \pm \\
1.5 \mathrm{a}\end{array}$ & $\begin{array}{c}65.7 \pm \\
2.2 \mathrm{a}\end{array}$ & $\begin{array}{c}34.4 \pm \\
1.7 \mathrm{a}\end{array}$ & $\begin{array}{l}8.2 \pm \\
0.7 b\end{array}$ & $\begin{array}{c}288.0 \pm \\
14.7 \mathrm{a}\end{array}$ & $\begin{array}{c}581.1 \pm \\
31.6 \mathrm{a}\end{array}$ & $\begin{array}{l}4.2 \pm \\
0.5 b\end{array}$ & $\begin{array}{c}10.7 \pm \\
0.4 \mathrm{~b}\end{array}$ & $\begin{array}{c}11.6 \pm \\
0.4 \mathrm{c}\end{array}$ \\
\hline FM3 & $\begin{array}{c}7.2 \pm \\
0.06 \mathrm{a}\end{array}$ & $\begin{array}{c}376.7 \pm \\
5.6 \mathrm{a}\end{array}$ & $\begin{array}{c}252.3 \pm \\
3.1 \mathrm{a}\end{array}$ & $\begin{array}{c}47.9 \pm \\
1.6 \mathrm{c}\end{array}$ & $\begin{array}{c}35.7 \pm \\
0.5 \mathrm{a}\end{array}$ & $\begin{array}{l}9.6 \pm \\
0.6 \mathrm{a}\end{array}$ & $\begin{array}{c}286.9 \pm \\
13.3 \mathrm{a}\end{array}$ & $\begin{array}{c}574.0 \pm \\
29.0 \mathrm{a}\end{array}$ & $\begin{array}{c}3.7 \pm \\
0.3 \mathrm{bc}\end{array}$ & $\begin{array}{c}11.3 \pm \\
0.3 b\end{array}$ & $\begin{array}{c}14.3 \pm \\
0.4 \mathrm{~b}\end{array}$ \\
\hline
\end{tabular}

2

3 CK (control), FM: Filtered mud, FM1 (FM:soil at 1:4), FM2 (FM:soil at 2:3), FM3 (FM:soil at 4 3:2); Means are followed by \pm standard deviation (SD) $(n=3)$. Letters show significant differences 5 between means ( $p>0.05)$. EC: Electrical conductivity; AK: Available potassium; AP: Available 6 phosphorous; TC: Total carbon; TN: Total nitrogen; TOC: Total organic carbon; TON: Total 7 organic nitrogen. 
Figure 1

Effects of filtered mud on soil enzyme activities (A) Cellulase (B) Phosphatase (C) Urease (D) $\beta$-glucosidase. CK (control), FM: Filtered mud; FM1 (FM:soil at 1:4), FM2 (FM:soil at 2:3), FM3 (FM:soil at 3:2).

The lowercase letters on the boxplots show significant differences between treatment means (Tukey's test, $p$ ).
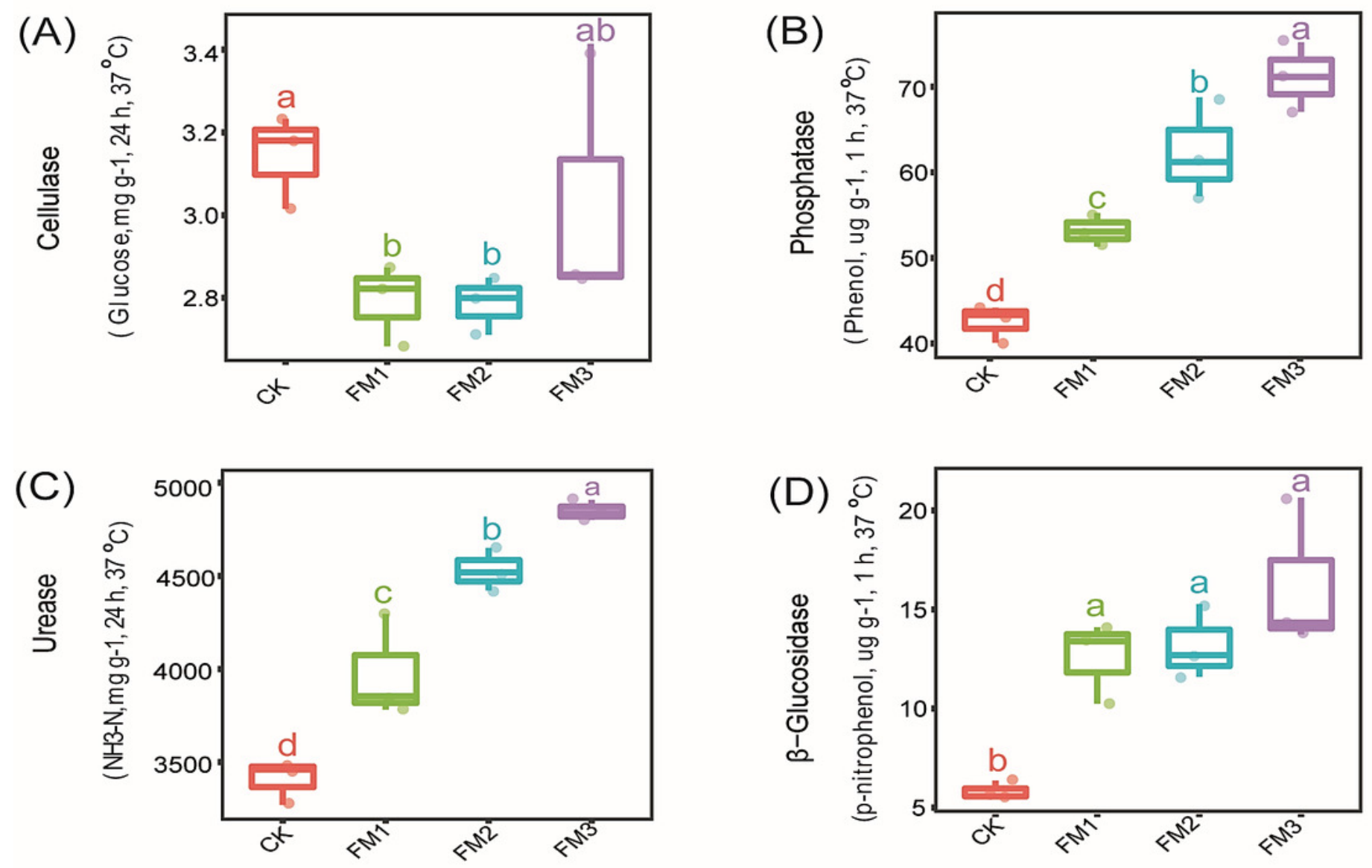
Figure 2

Agronomic characteristics of sugarcane. (A) PLH, plant height; (B) Chol, Leaves chlorophyll content; (C) NL, Number of leaves; (D) NT, Number of tillers; (E) PLD, Plant diameter.

The lowercase letter on the boxplots show significant differences between treatment means (Tukey's test, $p<0.05)$. CK (control), FM: Filtered mud; FM1 (FM:soil at 1:4), FM2 (FM:soil at 2:3), FM3 (FM:soil at 3:2).

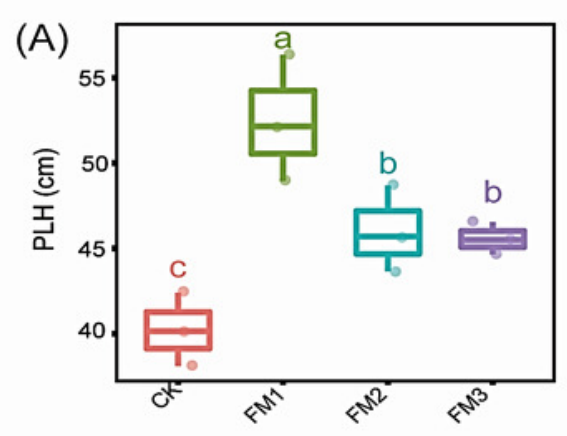

(B)

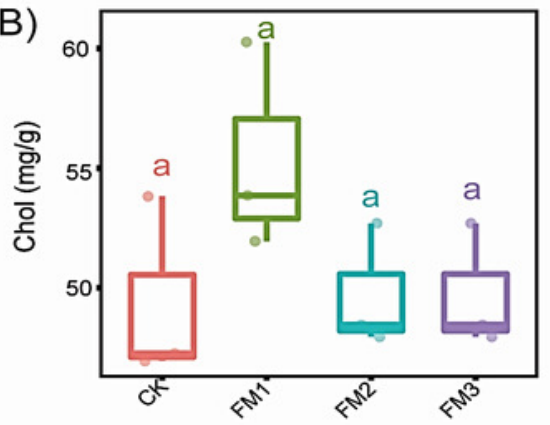

(C)

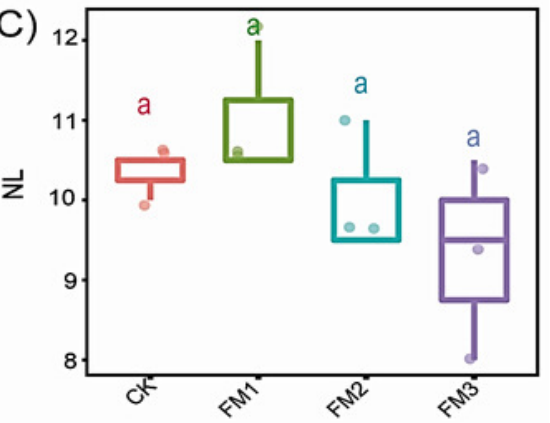

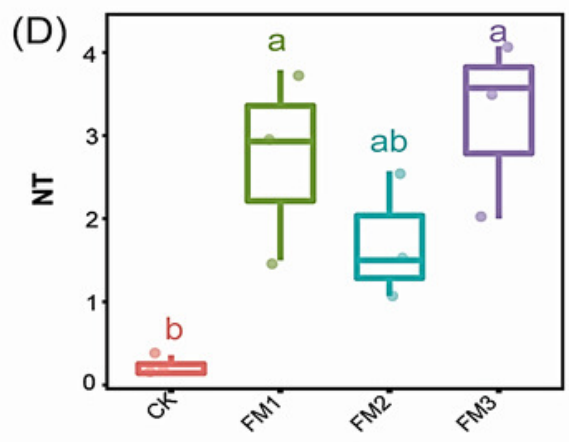

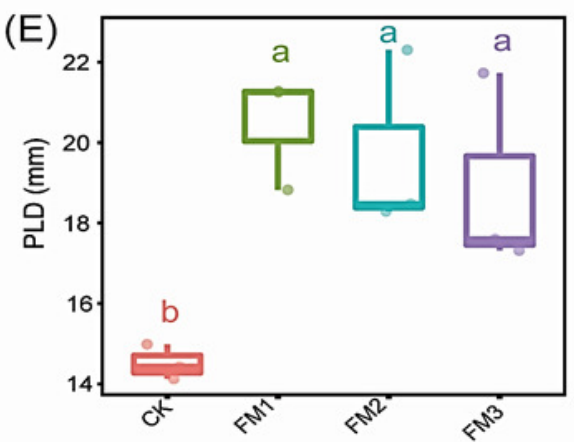


Figure 3

Relative abundance of soil (A) bacterial and (B) fungal community at phylum level.

CK (control), FM: Filtered mud, FM1 (FM:soil at 1:4), FM2 (FM:soil at 2:3), FM3 (FM:soil at 3:2).
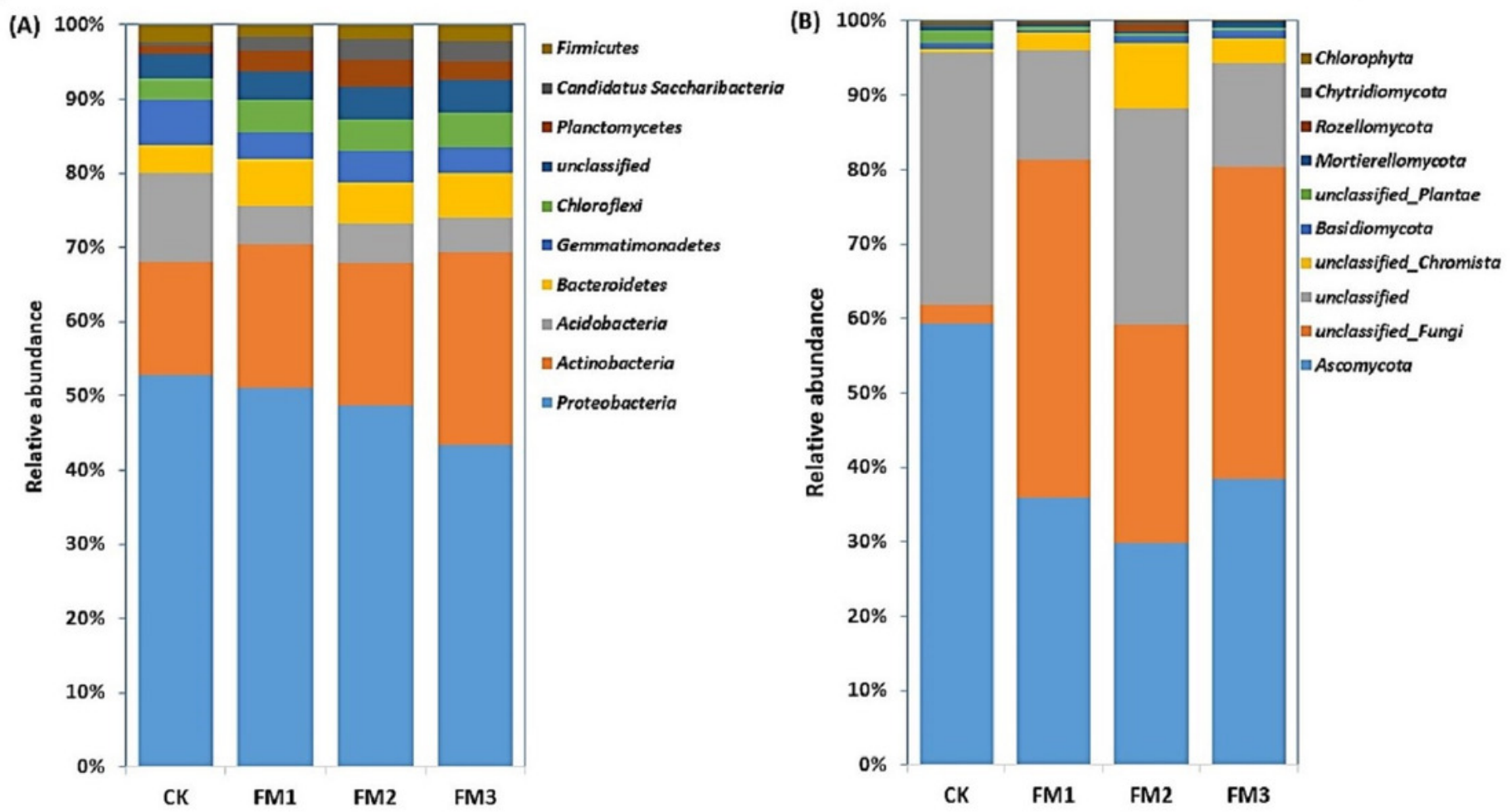
Figure 4

Relative abundance of soil (A) bacterial and (B) fungal community at class level. CK (control), FM: Filtered mud, FM1 (FM:soil at 1:4), FM2 (FM:soil at 2:3), FM3 (FM:soil at $3: 2)$.

CK (control), FM: Filtered mud, FM1 (FM:soil at 1:4), FM2 (FM:soil at 2:3), FM3 (FM:soil at 3:2).
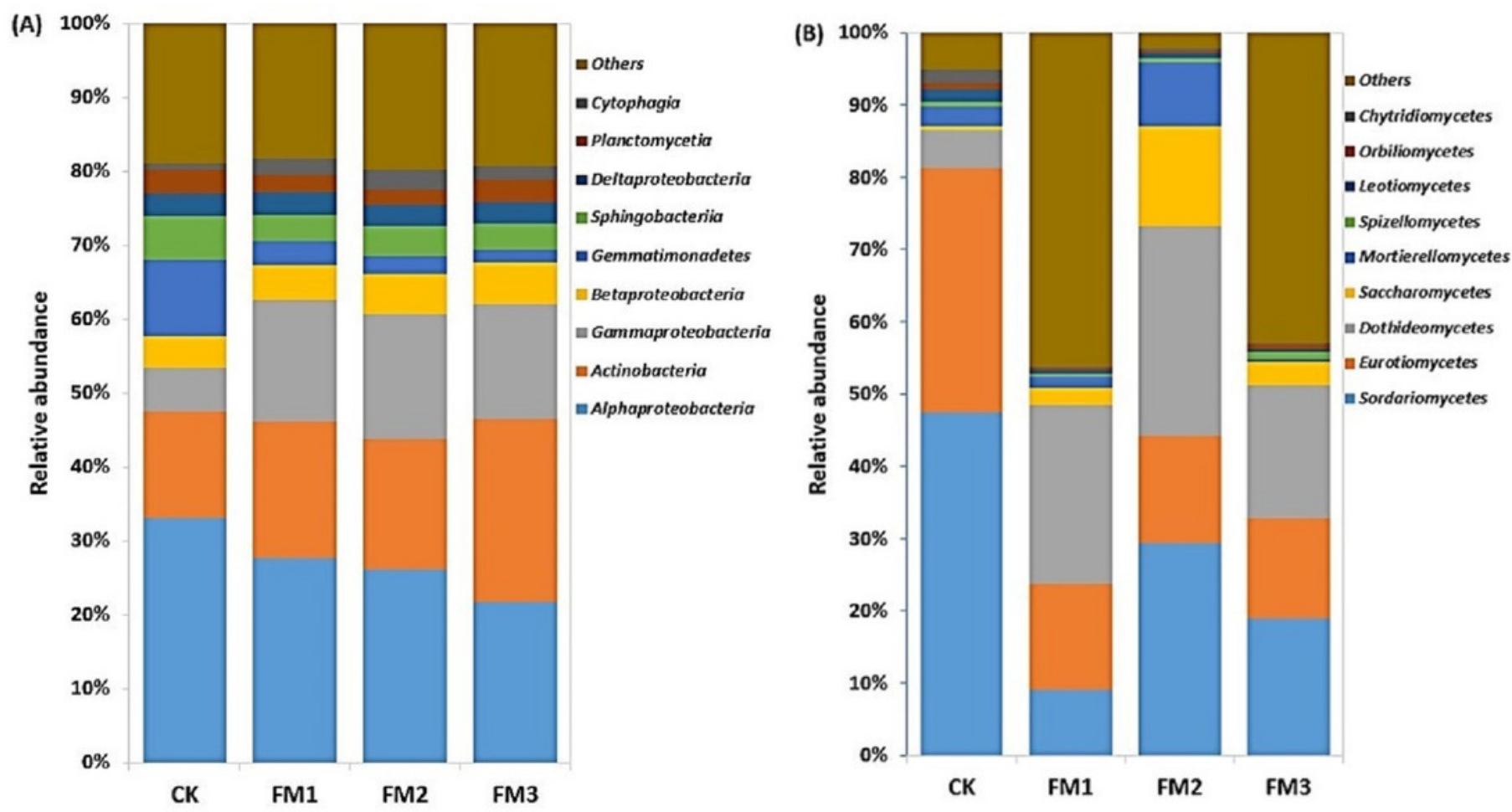
Figure 5

Alpha diversity indices of bacterial (A-D) and fungal (E-H) community: $(A, E) A C E,(B, F)$ Chaol, (C, G) Shannon, (D, H) Simpson. Error bars on the boxplots with different lowercase letters show significant differences between treatments (Tukey's test, [i]

Error bars on the boxplots with different lowercase letters show significant differences between treatments (Tukey's test, $p<0.05$ ). CK (control), FM: Filtered mud, FM1 (FM:soil at 1:4), FM2 (FM:soil at 2:3), FM3 (FM:soil at 3:2).

(A)

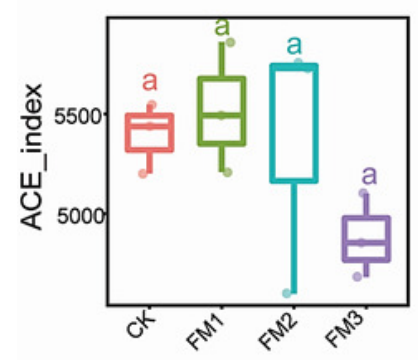

(E)

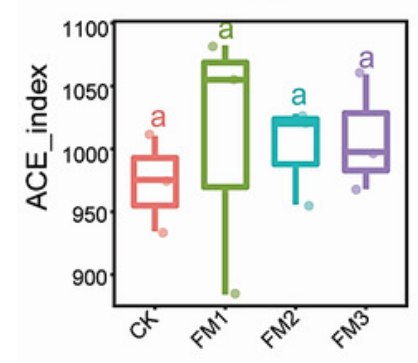

(B)

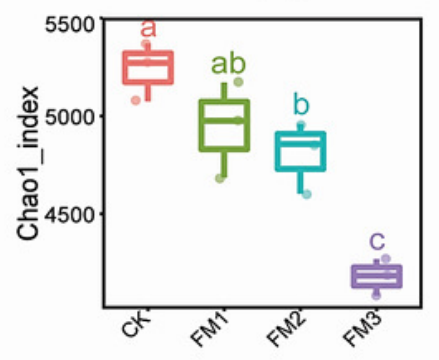

(F)

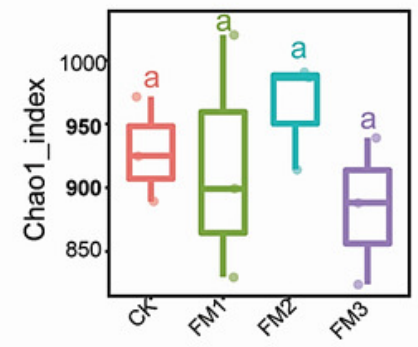

(C)

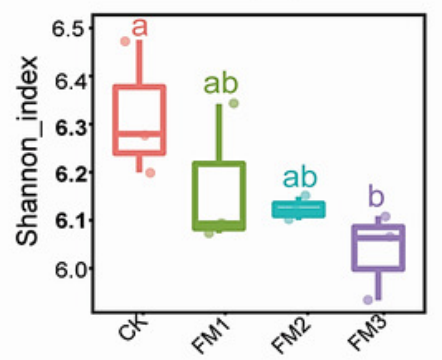

(G)

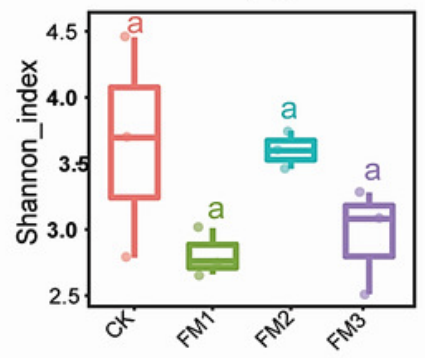

(D)

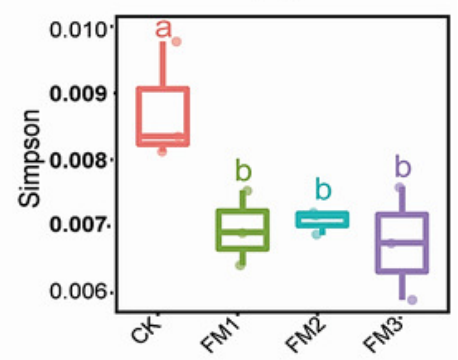

$(\mathrm{H})$

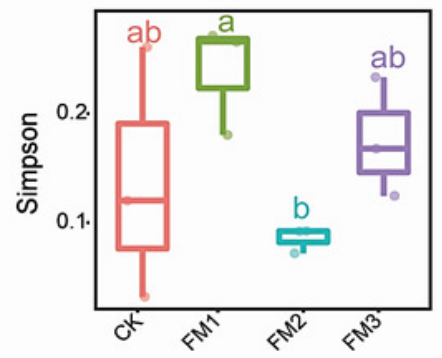


Figure 6

Principal coordinate analysis (PCOA) of $(A)$ bacteria and $(B)$ fungi communities across the FM amended treatments. CK (control), FM: Filtered mud; FM1 (FM:soil at 1:4), FM2 (FM:soil at 2:3), FM3 (FM:soil at 3:2).

CK (control), FM: Filtered mud; FM1 (FM:soil at 1:4), FM2 (FM:soil at 2:3), FM3 (FM:soil at 3:2).
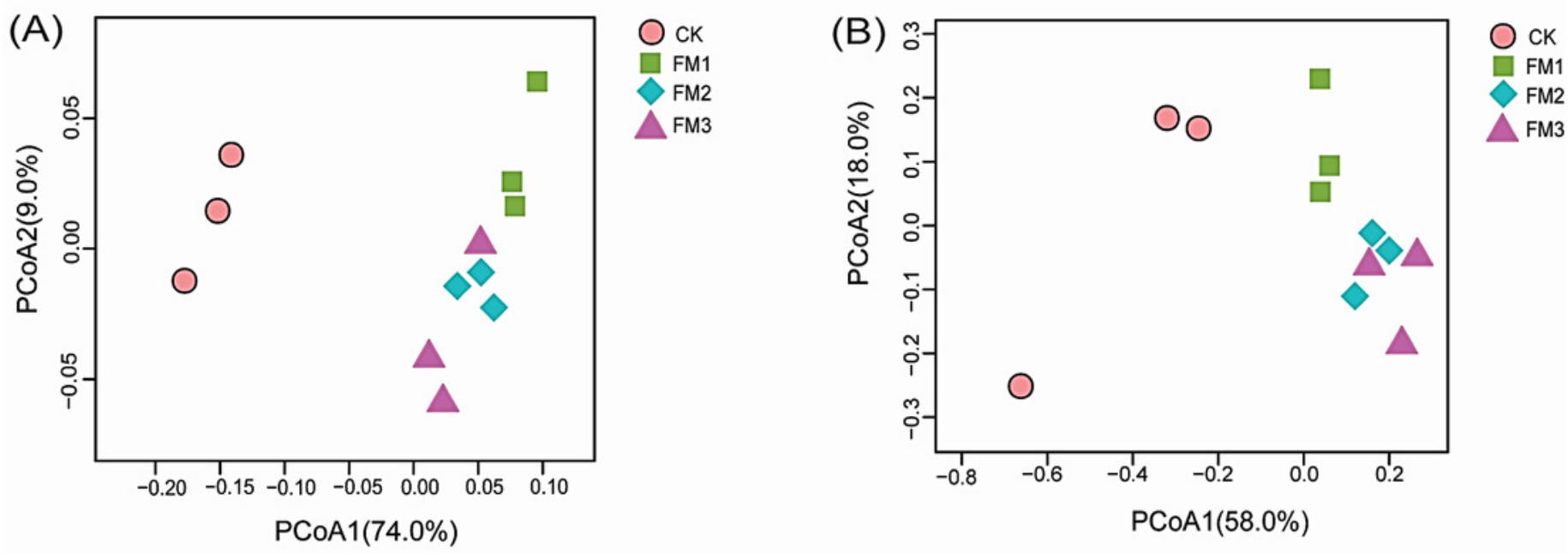


\section{Figure 7}

Redundancy analysis (RDA) of the relative abundance of dominant (A) bacteria and (B) fungi community and soil environmental variables across the filtered mud amended soil sample treatments. The length of soil variables arrow shows the relationship strengt

The length of soil variables arrow shows the relationship strength between the soil variables and the overall soil microbial community. CK (control), FM: Filtered mud, FM1 (FM:soil at 1:4), FM2 (FM:soil at 2:3), FM3 (FM:soil at 3:2); TN: Total nitrogen; TOC: Total organic carbon; TON: Total organic nitrogen; AP: Available phosphorous; TC_TN: Total carbon-Total nitrogen ratio.
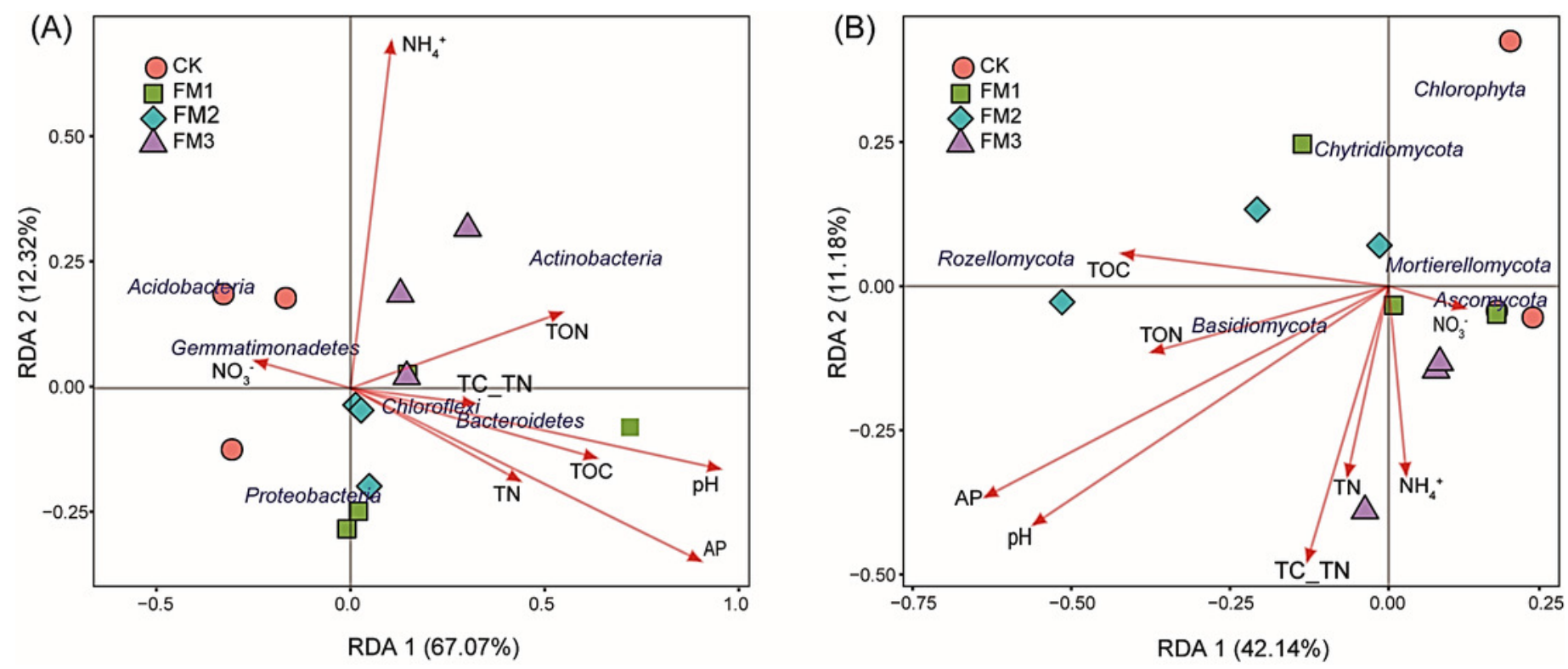